\title{
BIOLOGÍA REPRODUCTIVA DEL CRESPÍN TAPERA NAEVIA EN LA RESERVA DE LA ESCUELA GRANJA (UNL), ESPERANZA, SANTA FE, ARGENTINA
}

\author{
De la Peña, M. R. ${ }^{1}$
}

\begin{abstract}
RESUMEN
Se detallan los resultados obtenidos sobre las costumbres y la biología reproductiva de Tapera naevia. El estudio se realizó en un sector de monte de 30 hectáreas dentro de la Reserva de la Escuela Granja. Se especifican las especies parasitadas, las fechas de localización de los nidos y el contenido.

Se describen las características de los pichones, con peso corporal y medidas de pico, tarsometatarso y tibia.

Palabras clave: Tapera naevia, reproducción, pichones, Esperanza, Santa Fe.
\end{abstract}

\section{SUMMARY}

Reproductive biology of the Crespin (Tapera naevia) carried out in the Granja School Reserve (UNL), Esperanza, Santa Fe, Argentina.

New contributions to the reproductive biology of the Striped Cuckoo (Tapera naevia) are presented, mainly description and breeding of the nestlings.

The study was carried out in a sector of forest El Espinal biogeographical province of 30 ha.

The parasits species, date of localization of the nests and their content are mentioned.

The characteristics of th/e young, their corporal weight and bill measures, tarsus and tibia are described.

Key words: Tapera naevia, breeding, Esperanza, Santa Fe.

1.- Médico Veterinario. Académico Correspondiente, de la Academia Nacional de Agronomía y Veterinaria (Argentina) y Académico Honorario Correspondiente de la Universidad de Pilar (Paraguay). Profesor Honorario de la Universidad Nacional del Litoral.

3 de Febrero 1870. (3080) Esperanza, provincia de Santa Fe. Email: martin@fca.unl.edu.ar

Manuscrito recibido el 27 de febrero de 2006 y aceptado para su publicación el 8 de junio de 2006 . 